\title{
Plant size, nutrient composition and biomass productivity of oats and faba bean in intercropping, and the effect of controlling Rhopalosiphum padi (Hom., Aphididae) on these properties
}

\author{
JUHA HELENIUS \\ Department of Agricultural and Forest Zoology, University of Helsinki, \\ SF-00710 Helsinki, Finland
}

\begin{abstract}
Effects of mixed intercropping on plant size, content of mineral nutrients and biomass yields were examined in three field experiments in Southern Finland in 1983-1985. The stand types were monocrops and replacement series of mixtures with $2 / 3$ and $1 / 3$ or $1 / 3$ and $2 / 3$ of oats (Avena sativa) and faba bean (Vicia faba), respectively. In one of the experiments control of $R$. padi, by means of deltamethrin sprayings, was an additional experimental factor having two levels.

The height of stems or the above ground biomass of oats either were not affected or were increased by crop diversification. Bean plants remained smaller in the mixtures than in the monocrop. In plant size, there was a significant interaction between stand type and the effect of aphicide spraying: Oat benefitted most from being grown in the mixture containing most bean, and there was an indication (not statistically significant) that in these mixtures bean had proportionately higher weight loss. This result was interpreted as giving some support to the hypothesis of interspecific compensation between oats and bean against aphid damage to oats.

In oats, the content of $\mathrm{N}, \mathrm{P}, \mathrm{K}, \mathrm{Ca}$, and $\mathrm{Mg}$ all decreased from the stage of inflorescence emergence to the stage of the onset of milk development. Mixed cropping increased the content in oats of all these nutrients except $\mathrm{Ca}$. At the same time, contents of $\mathrm{P}$ and $\mathrm{K}$ in bean were decreased. The changes in growth form and composition in oats induced by intercropping are discussed from the point of view of host plant relationship and damage function of the aphid pest.

In terms of relative yield total (RYT), there was no overyielding in the dry matter, and in one case only was there overyielding in the nitrogen. During the period of population growth of $R$. padi, the daily maximum temperatures within the canopy were higher in the mixtures than in the monocrop of oats.
\end{abstract}

Index words: Avena sativa, Vicia faba, mixed intercropping, plant size, $\mathrm{N}, \mathrm{P}, \mathrm{K}, \mathrm{Ca}, \mathrm{Mg}$, biomass, insect pest management 


\section{Introduction}

Intercropping has gained interest in research primarily because of the two potential advantages it has to offer: overyielding, i.e. improved utilization of growth resources by the crop, and improved reliability from season to season. Intercropping cereals with legumes is a common practice all over the world. In Finland, the new cultivars of faba bean (Vicia faba Linnaeus) do better when grown together with oats (Avena sativa Linnaeus) as mixed intercrops than when grown as monocrops (Hovinen 1982, 1984).

In mixtures with faba bean, oats suffers higher infestation by cereal aphids, especially Rhopalosiphum padi (Linnaeus) (Hom., Aphididae) (Helenius 1989). This phenomenon made it possible to study mixtures of oats and faba bean from the point of view of pest management: Why did diversification of the crop lead to higher (and not lower, see RiscH et al. 1983) pest infestation in oats? The effects of mixed cropping on the colonization process of the aphid and on natural enemies have been reported earlier (Helenius 1989, 1990 a, b).

This paper describes the changes in the growth form and nutrient content of the component crops in the mixtures as compared to the monocrops; these changes induced by crop diversification may affect the host plant relationships and performance of the pest insects and may even alter the damage function. The temperatures within canopies in monocrops and mixtures were compared as a preliminary attempt to judge the extent to which an abiotic factor may contribute to the increased aphid numbers in the mixtures. Also, the hypothesis of interspecific yield compensation against pest damage (Trenbath 1976, Perrin 1977) was considered in this study. The results concerning grain yields and their formation, and the results concerning pest incidence in these systems, have been presented earlier (HELE. NIUS and RoNNI 1989). The results for oats in Experiment II of this study have been presented by RONNI (1987).

\section{Material and methods}

\section{Experimental designs}

Monocrops of oats cv. Nasta (Experiment I) or Puhti (Experiments II and III) and field beans cv. Mikko were compared with mixed intercrops of these two plants in three field experiments, carried out during 1983-1985 in Helsinki. The cv. Puhti ripens normally in 103 days and grows $98 \mathrm{~cm}$ high, cv. Nasta requires 4 days less and is on an average $9 \mathrm{~cm}$ shorter at maturity, and cv. Mikko requires 108 days and the mean height is $75 \mathrm{~cm}$ with a vide variation (Hovinen 1982). The experiments consisted of four different crop types:

(1) Monocrop of oats (notation OOO) with a normal seed density of 500 germinating seeds per $\mathrm{m}^{2}$.

(2) A mixture of $2 / 3$ oats and $1 / 3$ beans (OOB) following the replacement principle (de WIT 1960, see also WILLEy 1979): the monoculture sowing density of field beans was 100 germinating seeds per $\mathrm{m}^{2}$, and the OOB mixture was established by drilling $2 / 3 \times 500$ germinating seeds of oats and $1 / 3 \times 100$ germinating seeds of beans per $\mathrm{m}^{2}$.

(3) A mixture of $1 / 3$ oats and $2 / 3$ beans (OBB). The OBB mixture was established by following the same replacement principle used for the OOB mixture.

(4) Monocrop of beans (BBB) with a normal seed density of 100 germinating seeds per $\mathrm{m}^{2}$.

The mixtures were established by drilling the seed mixture. The rates of nitrogen fertilization were $80 \mathrm{~kg} / \mathrm{ha}$ for OOO, $40 \mathrm{~kg} / \mathrm{ha}$ for $\mathrm{OOB}$ and $\mathrm{OBB}$, and $0 \mathrm{~kg} / \mathrm{ha}$ for $\mathrm{BBB}$. The routine procedure for weed control was employed, applying dinoseb (Experiment I) or bentatzone (Experiments II and III) at the recommended rates.

In Experiment III control of $R$. padi, by means of sprayings, was an additional experimental factor having two levels. All the eight treatment combinations, i.e. four stand types times two spraying levels (unsprayed or sprayed), were randomized within each repli- 
cate block. During the sprayings $6.25 \mathrm{~g} / \mathrm{ha}$ deltamethrin was applied, for the first time on 20 June at oats G.S. (growth stage) 21 and for the second time on 3-4 July at oats G.S. 30, the same time as the first bean flowers opened.

The experimental design used in Experiment I (1983) was similar to that of Experiment II (1984), but the OOB mixture was absent and there were only two replications (blocks). In the other cases there were three replications. The experiments have been explained in detail in the previous papers in which they were referred to as follows:

\begin{tabular}{lccc}
\hline & \multicolumn{3}{c}{ Experiment } \\
\cline { 2 - 4 } & I (1983) & II (1984) & III (1985) \\
\hline Helenius 1989 & no. 6 & no. 7 & no. 5 \\
HelenIUS \& RoNNI 1989 & - & Exp. I & Exp. II \\
\hline
\end{tabular}

\section{Sampling and analyses}

Sampling from the plots was made at G.S. 70 , at the onset of the milk development stage of oats (TOTTMAN and BROAD 1987) and pod development of bean (STÜLPNAGEL 1984), on 26, 23 and 29 July in Experiments I, II and III, respectively. In Experiment I the sample consisted of four, and in Experiment II of two randomly chosen $0.25 \mathrm{~m}^{2}$ circles per plot. Within the circles, all oats and beans were removed by cutting at the soil surface level. In Experiment III, no area based sampling was done, but eight oat and bean plants were randomly sampled within the inner rows of each plot.

The height and the dry weight (above ground biomass) of stems were measured from the samples. The height was measured by stretching the shoot to the tip of the uppermost leaf or flower, whichever reached furthest. The data for dry weight in oats became inconsistent, as in Experiment I all stems, including adventitious stems, had been weighed, while in Experiment II whole plants, main stems and tillers combined, had been weighed. Only in Experiment III were the main stems weighed separately from the adventitious stems.

In addition to the sampling at the "harvestable stage' G.S. 70, in Experiment II sampling for nutrient content of oats was made on 25 June at G.S. 37 (flag leaf just visible) and for height of main stem and nutrient content of oats at G.S. 55 (inflorescence emergence) and height of bean at G.S. 65 (full-blossom) on 9 July. In Experiment III sampling for height of main stem was made on 2-3 July at G.S. 31 of oats (first node detectable) and at G.S. 65 of bean, and for height, weight and nitrogen content of main stems of oats on 18 July at G.S. 55. The sampling methods were the same as at G.S. 70.

For oats, total nitrogen content was analysed in all the experiments, phosphorus and potassium in experiments I and II, and calcium and magnesium in Experiment II only. For bean, no analyses were performed in Experiment $\mathrm{I}$, nitrogen was analysed in experiments II and III, and phosphorus, potassium, calcium and magnesium in Experiment II only. The nutrients were analysed, following the standard procedures of Association of Official Analytical Chemists (Williams 1984), by Viljavuuspalvelu Co. (Helsinki).

Comparisons of the mixtures with the monocrops were made in terms of relative yield, using the concept of Relative Yield Total (=RYT: de WIT and van den BERGH 1965).

In Experiment III, daily minimum and maximum temperatures at ca. $2 \mathrm{~cm}$ above soil surface level within the canopy were measured by minimum-maximum thermometers. One thermometer was placed in the middle of each plot. The measurements were made during population growth of $R$. padi, and only the insecticide treated plots were used.

Standard analysis of variance tests were utilized to test for statistical significance. The following abbreviations are used: S.E. for standard error of mean (with the mean given as \pm S.E.), G.S. for growth stage and D.M. for dry matter. 


\section{Results}

\section{Plant size}

In Experiment III, mixed cropping significantly increased the above ground biomass of oats. At G.S. 70 the main stems in the monocrop and OOB mixture weighed the same, but were $25.2 \%$ heavier in the OBB mixture. At the same time, the adventitious stems weighed $0.29 \pm 0.07,0.38 \pm 0.10$ and $1.02 \pm 0.22 \mathrm{~g} /$ plant in the monocrop, ООВ mixture and OBB mixture, respectively $(n=6$, $p<0.01$ ). Aphicide spraying had no significant effect on the weight of the adventitious stems.

In the weight of the main stems there was a significant $(p<0.001)$ interaction between growth stage, stand type and spraying. In the monocrop the biomass growth from G.S. 55 to G.S. 70 was $17.9 \%$ and did not depend on the sprayings. In the OOB mixture the estimated growth in the unsprayed plots was negligible, while in the sprayed plots the growth was $24.1 \%$. In this mixture, the gain in weight by sprayings was not yet detectable at G.S. 55, but at G.S. 70 it averaged $33.3 \%$. In the OBB mixture the growth was, on an average, $16.6 \%$ in the unsprayed plots but $27.1 \%$ in the sprayed plots, and the increase obtained by the sprayings was $11.8 \%$ already at G.S. 55, and $22.0 \%$ at G.S. 70 (Fig. 1).

In Experiment III, there was also a significant $(p<0.001)$ three way interaction in shoot height between the growth stage, stand type and spraying with insecticide. In the monocrop, the height increased $11.9 \%$ from G.S. 55 to G.S. 70, and the increase did not depend on spraying. However, in the mixtures the growth in height during this period was, on an average, only $5.0 \%$ if not sprayed but $20.1 \%$ if sprayed with insecticide. This resulted in oats shoots $21.8 \%$ taller in the sprayed mixtures as compared to those in the unsprayed mixtures (Fig. 2).

In Experiments I and II, there were no significant effects of mixed cropping on the size of oats. In Experiment II, the height of the

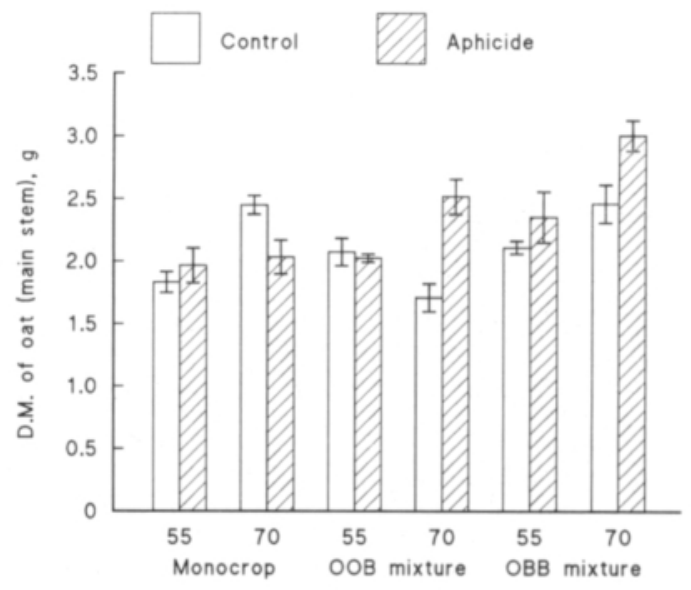

Fig. 1. Above ground biomass of main stems of oats when not sprayed (Control) or sprayed (Aphicide) against cereal aphids, at growth stages (G.S.) 55 and 70 in the monocrop, OOB mixture ( $1 / 3$ faba beans) and OBB mixture ( $2 / 3$ beans) (Experiment III).

oats stems increased $39.7 \%$ from G.S. 55 to G.S. $70(p<0.001)$.

The leaf/stem ratio in oats was not significantly affected by mixed cropping, but the insecticide treatment in Experiment III reduced the ratio by $22 \%$ from $0.23 \pm 0.01$ to $0.18 \pm 0.01(\mathrm{n}=9, p<0.01)$.

The stems of bean tended to remain lighter in the mixtures (Fig. 3), significantly so in

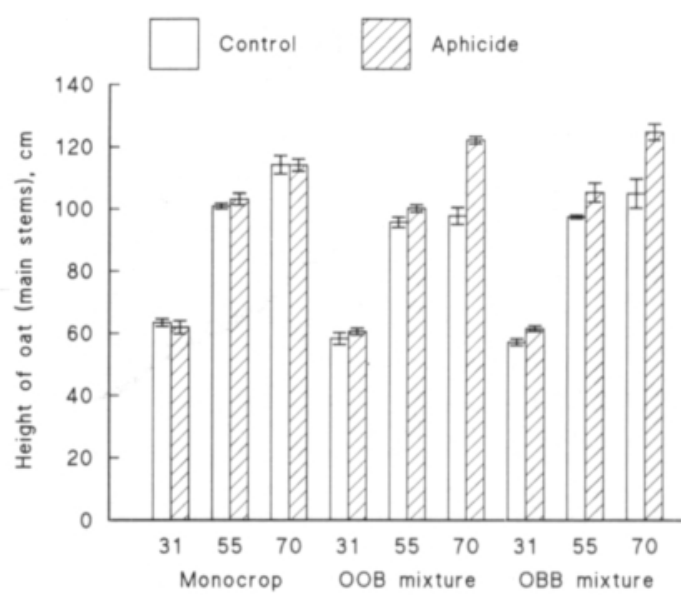

Fig. 2. Height of the main stems of oats when not sprayed (Control) or sprayed (Aphicide) against cereal aphids, at growth stages (G.S.) 31, 55 and 70 in the monocrop, OOB mixture and OBB mixture (Experiment III). 


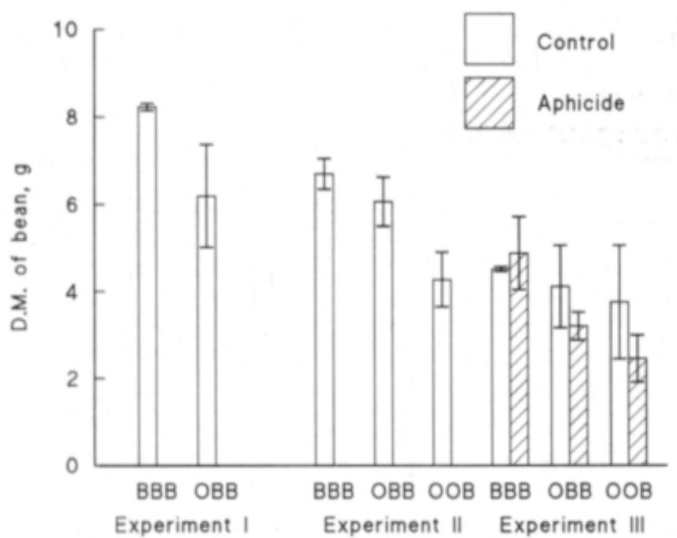

Fig. 3. Above ground biomass of bean at growth stage 70 in the monocrop, OBB mixture and OOB mixture. In Experiment III, the effect of aphicide spraying is shown.

Experiment II, where the reduction from the monocrop to the OBB mixture and $\mathrm{OOB}$ mixture was $9.4 \%$ and $36.1 \%$, respectively $(p<0.01)$. In Experiment I, the differences were not significant and in Experiment III, these were statistically only indicative $(p=0.06)$. In the plots treated with insecticide, as compared to the untreated plots, the mean weight of stems was $8.2 \%$ higher in the monocrop, but $22.1 \%$ and $34.6 \%$ lower in the OBB mixture and $\mathrm{OOB}$ mixture, respectively: howev- er, the effect of spraying $(p=0.22)$ or interaction spraying $\times$ stand type $(p=0.36)$ were not statistically significant.

The reduction in stem weight of bean was accompanied by reduction in height. In Experiment II, the reduction in height was $1.1 \%$ and $15.6 \%$ in the OBB mixture and OOB mixture, respectively, as compared to monocrop $(p<0.001)$. In this case the growth in height from G.S. 65 to G.S. 70 was $50.4 \%(p<0.001)$, equally in all the stand types. In Experiment III, there was a significant interaction in stem height between growth stage and stand type $(p<0.05)$; the mean heights at G.S. 65 were $31.6 \pm 0.8,37.8 \pm 1.6$ and $41.8 \pm 1.6 \mathrm{~cm}$, but the increase from that stage was largest in the monocrop and smallest in the OOB mixture, resulting in mean heights of $95.3 \pm 3.7$, $89.3 \pm 3.7$ and $85.8 \pm 4.6 \mathrm{~cm}$ at G.S. 70 in the monocrop, $\mathrm{OBB}$ mixture and $\mathrm{OOB}$ mixture, respectively $(n=6)$.

\section{Nutrient content}

The results on the effects of stand type on nutrient content of the plants varied from one experiment to another.

In Experiment I, there were no differences between the monocrop and the mixture in the

Table 1. Content of mineral nutrients, g/kg D.M., in the above ground tissues of oats, at growth stages 37,51 and 70 in the monocrop (OOO), OOB miture ( $1 / 3$ faba beans) and OBB mixture ( $2 / 3$ beans) (Experiment II). Mean \pm S.E., $n=3$.

\begin{tabular}{lccccc}
\hline & Nitrogen & Phosphorus & Potassium & Calcium & Magnesium \\
\hline G.S. 37 & & & & \\
OOO & $30.3 \pm 0.8$ & $4.2 \pm 0.1$ & $32.2 \pm 0.5$ & $6.1 \pm 0.2$ & $1.28 \pm 0.05$ \\
OOB & $29.9 \pm 1.6$ & $4.5 \pm 0.2$ & $32.1 \pm 0.5$ & $6.1 \pm 0.4$ & $1.35 \pm 0.05$ \\
OBB & $34.9 \pm 0.6$ & $5.1 \pm 0.2$ & $35.9 \pm 1.3$ & $6.5 \pm 0.0$ & $1.52 \pm 0.04$ \\
G.S. 51 & & & & \\
OOO & $17.2 \pm 1.7$ & $3.7 \pm 0.2$ & $25.2 \pm 1.4$ & $3.9 \pm 0.5$ & $0.98 \pm 0.07$ \\
OOB & $20.0 \pm 0.6$ & $4.2 \pm 0.2$ & $25.8 \pm 1.6$ & $4.4 \pm 0.2$ & $1.08 \pm 0.06$ \\
OBB & $25.2 \pm 1.4$ & $5.2 \pm 0.2$ & $31.9 \pm 1.8$ & $5.2 \pm 0.2$ & $1.27 \pm 0.03$ \\
G.S. 70 & & & & \\
OOO & $14.0 \pm 0.3$ & $3.3 \pm 0.1$ & $20.4 \pm 0.6$ & $3.2 \pm 0.2$ & $0.94 \pm 0.05$ \\
OOB & $15.8 \pm 0.7$ & $4.0 \pm 0.1$ & $23.2 \pm 0.9$ & $3.7 \pm 0.1$ & $1.08 \pm 0.02$ \\
$\quad$ OBB & $18.6 \pm 0.9$ & $4.5 \pm 0.3$ & $27.0 \pm 1.1$ & $3.9 \pm 0.3$ & $1.07 \pm 0.02$ \\
level of $p:$ & & & & \\
G.S. & 0.001 & 0.01 & 0.001 & 0.001 & n.s. \\
Crop & 0.05 & 0.01 & 0.05 & n.s. & 0.001 \\
Interaction & n.s. & n.s. & & & \\
\hline
\end{tabular}


nitrogen, phosphorus or potassium contents in oats. The mean contents at G.S. 70 were $11.0 \pm 0.3 \mathrm{~N}, 2.2 \pm 0.1 \mathrm{P}$ and $24.0 \pm 0.7 \mathrm{~K}$ in $\mathrm{g} / \mathrm{kg}$ dry matter $(\mathrm{n}=12)$. Only nitrogen was analysed in Experiment III, and again, there were no differences between stand types: In oats, the mean nitrogen content at G.S. 55 was $15.1 \pm 0.5(\mathrm{n}=18)$, and it was not yet influenced by spraying with insecticide, but at G.S. 70 the mean content in the unsprayed plots was $14.4 \pm 0.6(n=9)$, and significantly lower, $12.5 \pm 0.5 \mathrm{~g} / \mathrm{kg}$ dry matter $(\mathrm{n}=9)$ in the sprayed plots (interaction between growth stage and spraying: $p<0.05$ ). The mean content in bean at G.S. 70 was $29.5 \pm 0.4 \mathrm{in} \mathrm{g} / \mathrm{kg}$ dry matter $(\mathrm{n}=18)$.

In Experiment II, mixed cropping significantly increased the nitrogen, phosphorus, potassium and magnesium contents of oats. In all these nutrients there was a steady decrease from G.S. 37 to G.S. 70. Calcium was not affected by mixed cropping but, like the other nutrients, it also decreased over time (Table 1). The only statistically significant effects on bean were the decreases in phosphorus and potassium contents in mixed cropping $(p<0.05)$ (mean \pm S.E. in $\mathrm{g} / \mathrm{kg}$ dry matter, $\mathrm{n}=3)$ :

\begin{tabular}{lcc}
\hline & $\mathrm{P}$ & $\mathrm{K}$ \\
\hline bean monocrop & $4.1 \pm 0.1$ & $26.6 \pm 0.3$ \\
OBB mixture & $3.9 \pm 0.1$ & $25.0 \pm 0.7$ \\
OOB mixture & $3.5 \pm 0.1$ & $22.2 \pm 0.9$ \\
\hline
\end{tabular}

The mean contents of the other nutrients in bean were $32.9 \pm 0.4 \mathrm{~N}, 7.9 \pm 0.2 \mathrm{Ca}$, and $1.60 \pm 0.04 \mathrm{Mg}$ in $\mathrm{g} / \mathrm{kg}$ dry matter $(\mathrm{n}=9)$.

\section{Biomass and nitrogen yields}

At G.S. 70, the highest above ground biomass yields were always produced by oat monocrop and the lowest by bean monocrop. The mixtures were intermediate in this respect.

Table 2. Above ground biomass yields, D.M. kg/ha, and relative yields of the component crops and the relative total yields (RYT) in the mixtures, at G.S. 70 (Experiments I and II). Mean \pm S.E., $\mathrm{n}=6$.

\begin{tabular}{|c|c|c|c|c|c|c|c|}
\hline & & Oats & rel. & Bean & rel. & Total & RYT \\
\hline \multirow[t]{2}{*}{ Oat monocrop } & Exp. I & $9308 \pm 962$ & 100 & . & . & & \\
\hline & Exp. II & $8268 \pm 638$ & 100 & . & . & & \\
\hline OOB mixture & Exp. II & $5664 \pm 523$ & 68 & $1261 \pm 309$ & 24 & $6925 \pm 412$ & 92 \\
\hline \multirow[t]{2}{*}{ OBB mixture } & Exp. I & $2386 \pm 171$ & 26 & $4139 \pm 430$ & 73 & $6526 \pm 436$ & 99 \\
\hline & Exp. II & $2626 \pm 356$ & 31 & $4094 \pm 521$ & 78 & $6720 \pm 783$ & 109 \\
\hline \multirow[t]{2}{*}{ Bean monocrop } & Exp. I & . & . & $5638 \pm 547$ & 100 & & \\
\hline & Exp. II & . & . & $5284 \pm 636$ & 100 & & \\
\hline
\end{tabular}

Table 3. Absolute and relative nitrogen yields, $\mathrm{kg} \mathrm{N} / \mathrm{ha}$, in the above ground biomass (c.f. Table 1).

\begin{tabular}{llrrrrrr}
\hline & & Oats & rel. & Bean & rel. & Total & RYT \\
\hline Oat monocrop & Exp. I & 102.4 & 100 &. &. & & \\
& Exp. II & 115.8 & 100 &. &. & & \\
OOB mixture & Exp. II & 89.5 & 77 & 41.5 & 24 & 131.0 & 101 \\
OBB mixture & Exp. I & 26.2 & 26 & 124.2 & 73 & 150.4 & 99 \\
& Exp. II & 48.8 & 42 & 134.7 & 78 & 183.5 & 120 \\
Bean monocrop & Exp. I &. &. & 169.1 & 100 & 100 & \\
& Exp. II & - &. & 173.8 & 100 & \\
\hline
\end{tabular}

Note: Nitrogen yields were calculated from the dry matter yields using the determined nitrogen contents except for bean in Experiment $\mathrm{I}$, where a nitrogen content of $30 \mathrm{~g} / \mathrm{kg}$ dry matter was assumed. 
The RYT values remained close to unity in all the cases (Table 2).

Using the results from the nitrogen determinations given above, the nitrogen yields can be calculated (for bean in Experiment I, $30.0 \mathrm{~g}$ $\mathrm{N} / \mathrm{kg}$ dry matter is assumed): Either the bean monocrop or the OBB mixture produced the highest nitrogen yields in the harvestable green biomass. In terms of RYT, because of the relatively high nitrogen yield in oats, only the OBB mixture in Experiment II overyielded, by $20 \%$ (Table 3).

\section{Temperature within canopy}

Over the time of the growth and peak density of the $R$. padi populations, at G.S. 16-31 from 26 June to 8 July (from the onset of tillering to stem elongation of oats), the means of the daily minimum temperatures did not differ between the oat monocrop and mixtures, but in the bean monocrop, the minimums were $0.8^{\circ} \mathrm{C}$ lower than in the other stand types $(p<0.001)$. During the same period, the means of the daily maximum temperatures were $1.0^{\circ} \mathrm{C}$ higher in the OBB mixture than in the oat monocrop or OOB mixture, and still $1.3^{\circ} \mathrm{C}$ higher in the bean monocrop than in the OBB mixture $(p<0.001)$.

\section{Discussion}

In mixtures with faba bean, oats may grow taller than in the monocrops, whereas bean usually remains shorter; this is due to the dominance of oats in the competition (VulLIOUD 1969, KortesmaA 1982, Hovinen 1983). In their study on mixtures of barley and faba bean, MARTIN and SNAYDON (1982 b) showed that root competition alone can increase the shoot weight of the cereal component and deerease that of bean. In the present study, a decrease in bean weight and height, and in one case an increase in oats weight and height could be shown.

Controlling the cereal aphids resulted in a relatively greater increase in the growth of oats in the mixtures than in the monocrop: In this case, the aphid loads at the peak population densities were $18 \%$ and $28 \%$ higher in the unsprayed OOB mixture and OBB mixture than in the monocrop (Helenius 1989, HeLENIUS and RoNnI 1989). The trends in the heights of the stems of bean in the sprayed plots, although not statistically significant, supported the hypothesis of compensatory dynamics in the growth of the component crops in the mixtures. An indication of a similar interaction between stand type and the effect of sprayings on grain yield has been reported earlier, from the same experiment (Helenius and Ronni 1989). More substantial evidence of this kind would be needed to encourage research on developing risk adverse intercropping systems, especially in order to respond to the need to overcome plant protection problems in low input sustainable agriculture. The case also serves to illustrate the point that control thresholds for pesticide use intended for monocrops do not necessarily apply to intercrops.

Mixed cropping had varying effects on the mineral nutrient contents in the above ground tissues of oats and bean. In two experiments out of the three, there was no change in the nitrogen content of oats. In one case, nitrogen and all the other minerals that were analysed, except calcium, were increased in oats by mixed cropping. The differences between the monocrop and the mixtures were consistent over the three growth stages that were sampled, in spite of the steady decrease in the contents in the course of growth and development. Along with the increase in oats, phosphorus and potassium were decreased in bean. MARTIN and SNAYdon (1982 a, b) also found varying effects of intercropping on the nitrogen, phosphorus and potassium contents of barley and faba bean: Most consistent was the increase in nitrogen in barley, and it seemed as if barley was a stronger competitor for $\mathrm{P}$ and $\mathrm{K}$. By using ${ }^{15} \mathrm{~N}$ labelling, PATrA et al. (1986) showed that up to $28 \%$ of the $\mathrm{N}$ uptake by the cereal (maize) can be obtained by transfer of biologically fixed $\mathrm{N}$ by the legume (cowpea) in intercropping. The most likely expla- 
nation for the results presented here would be a relieved intraspecific competition for nitrogen in oats and dominance of oat in the interspecific root competition for the other nutrients, such as phosphorus and potassium, in the mixtures with faba bean (c.f. MARTIN and SNAYDON 1982 a).

There was no evidence for transgressive yielding in harvestable biomass in the mixtures. However, the relative yields of bean in the OBB mixtures tended to be higher than expected on the basis of the $60 \%$ sowing ratio. MARTIN and SNAYDON (1982 a) reported overyielding in alternate row mixtures of barley and faba bean, but not in the within row mixtures. There is some evidence for superiority of alternate row systems also with respect to the intercrops of oats with faba bean (unpublished results). Concerning nitrogen yields, on both absolute and relative bases, the best alternatives were either the bean monocrops or the OBB mixtures. In one case, the latter overyielded by $20 \%$, here, the relatively higher uptake of nitrogen by oats contributed most. Obviously, OBB mixture could provide an alternative for making silage as green fodder (InGAlls et al. 1979, Kiviniemi 1982).

Changes induced by intercropping in growth form or nutritive quality of a host plant can affect pest numbers. In this study, the focus was on the aphid pest specific to the component crop, namely oats, which was the dominating of the two. As expected, competition between the component species had a greater effect on the growth form of the dominated beans. The most marked response in the growth form of oats was the increase in tiller number, which could be attributed to the reduced plant density rather than to interspecific interaction (HelenIUS and RoNNI 1989). No changes in leaf/stem ratio could be proved, but a marked increase in shoot weight was shown in Experiment III, where the methods to estimate this were more appropriate than in the other two experiments. The difference between the monocrop and the OBB mixture was evident already at inflorescence emergence, two weeks after the peaking of the aphid populations. Theoretically, even a small difference between monocrops and mixtures in size of stems during the latter parts of the aphid population development (exponential growth and peak) could contribute to the difference in numbers per stem of cereal aphids (see HeLENIUS 1989). Larger stems could delay the effects of intraspecific competition by providing more space, thus delaying crowding in the aphid colonies, and by tolerating more sap feeding, thus delaying deterioration of the plant as a host to the aphids.

Plant mineral content, especially that of nitrogen (e.g. MATTSON 1980), often relates to its quality as a host to an insect herbivore. Content of free amino acids in tissues of a cereal plant has been shown to affect behaviour and reproduction of $R$. padi (HAVLíčKoví 1987, Weibull 1987). There was no consistent pattern in the effect of mixed cropping on the nitrogen content of oats, and no conclusions can be drawn concerning the possible contribution of host plant nutritional quality to the difference in cereal aphid infestation between the monocrops and mixtures. Controlling the aphids decreased the nitrogen content in oats, obviously because the increase in dry matter growth was relatively more than the increase in nitrogen uptake.

The measurements of temperatures within the canopies indicated $1^{\circ} \mathrm{C}$ higher daily maximums in the OBB mixture than in the monocrop of oats. This difference was measured just above soil surface level, where before the canopy closure the maximums are higher than at upper layers due to heating of the soil (CORdukes and RoberTSON 1963). Temperature affects development time, survival and fecundity of cereal aphids (e.g. DEAN 1974), but such a small difference as found here between the crop types in maximum temperatures only is not likely to be critical to the growth rate of aphid populations. However, it is obvious that microclimatic differences between monocrops and intercrops in some cases may become a major cause for differences in 
pest infestations (e.g. Kyamanywa and AmPOFO 1988).

An agronomically important emergent property of a multispecies crop community is the possibility of compensatory dynamics in growth of component crops. This is a feature which should be taken into account when aiming to improve reliability in arable field cropping. As indicated in this study, the interspecific dynamics of component crops in intercropping could be utilized in crop protection by planning communities where compensation against pest damage to one of the component crops is operative. Crop diversification is likely to lead to changes in component crops, in their growth form and nutritional quality, and to other changes in the crop community that are important to the population dynamics of pest insects, thereby affecting both the numbers and the damage function of the pests. These effects together with the interspecific dynamics of the crop species determine the level of resistance against pest damage in an intercropping system.

Acknowledgements. I would like to thank Päivi Ronni, M.Sc. (Agr. \& For.), for help in compiling the data, Prof. Anna-Liisa Varis for comments on the manuscript and Sevastiana Ruusamo, M.A., for its linguistic revision. The study was funded by the National Research Council for Agriculture and Forestry, and by the Tiura Foundation.

\section{References}

Cordukes, W.E. \& Robertson, G.W. 1963. Note on the temperature distribution within an oat crop. Canadian J. Plant Sci. 43: 235-239.

DeAn, G.J. 1974. Effect of temperature on the cereal aphids Metopolophium dirhodum (Wlk.), Rhopalosiphum padi (L.) and Macrosiphum avenae (F.) (Hem., Aphididae). Bull. Ent. Res. 63: 401-409.

Havlí̌KovÁ, H. 1987. Behaviour and reproduction of cereal aphids in relation to changes in the content of water and free amino acids in wheat during the growing season. J. Appl. Ent. 103: 142-147.

Helenius, J. 1989. The influence of mixed intercropping of oats with field beans on the abundance and spatial distribution of cereal aphids (Homoptera, Aphididae). Agric. Ecosystems Environ. 25: 53-73.

- 1990 a. Effect of epigeal predators on infestation by the aphid Rhopalosiphum padi and on grain yield of oats in monocrops and mixed intercrops. Entomol. Exp. Appl. 54: 225-236.

- 1990 b. Incidence of specialist natural enemies of Rhopalosiphum padi (L.) (Homoptera, Aphididae) on oats in monocrops and mixed intercrops with fapa bean. J. Appl. Ent. 109: 136-143.

- \& RonNI, P. 1989. Yield, its components and pest incidence in mixed intercropping of oats (Avena sativa) and field beans (Vicia faba). J. Agric. Sci. Finland 61: $15-31$.

HovıNEN, S. 1982. Hankkijan Mikko-hărkäpapu. Hankkijan Kasvinjal.lait. Tied. 7. 20 p.

- 1983. Seosviljely palkoviljojen viljelyn varmentajana Suomessa. Sivulaudaturtyő, 102 p. Univ. Helsinki, Department of Crop Husbandry.

- 1984. Hankkijan Ukko-härkăpapu. Hankkijan Kasvinjal.lait. Tied. 14. $13 \mathrm{p}$.

Ingalls, J.R., Sharma, H.R., Devlin, T.J., Bareeba, F.B. \& CLARK, K.W. 1979. Evaluation of whole plant fababean forage in ruminant rations. Can. J. Anim. Sci. 59: 291-301.

Kiviniemi, J. 1982. Harvesting methods of legumes. The 2nd Nat. Symp. Biol. Nitrogen Fixation. Nitrogen Project Rep. 1: 85-90. SITRA, Helsinki.

KortesmaA, T. 1982. Härkäpavun ja viljan seosviljely vaihtoehtona valkuaisrehun tuotannossa. Pro gradu -tyő. 114 p. Univ. Helsinki, Department of Crop Husbandry.

Kyamanywa, S. \& Ampofo, J.K.O. 1988. Effect of cow$\mathrm{pea} / \mathrm{maize}$ mixed cropping on the incident light at the cowpea canopy and flower thrips (Thysanoptera: Thripidae) population density. Crop Protection 7: 186-189.

MarTin, M.P.L.D. \& Snaydon, R.W. 1982 a. Intercropping barley and beans. I. Effects of planting pattern. Exp. Agric. 18: 139-148.

- \& SNAYdon, R.W. 1982 b. Root and shoot interactions between barley and field beans when intercropped. J. Appl. Ecol. 19: 263-272.

Mattson, W.J. Jr, 1980. Herbivory in relation to plant nitrogen content. Ann. Rev. Ecol. Syst. 11: 119-161.

Patra, D.D., Sachdev, M.S. \& Subbiah, B.V. 1986. ${ }^{15} \mathrm{~N}$ studies on the transfer of legume-fixed nitrogen to associated cereals in intercropping systems. Biol. Fertil. Soils 2: 165-171.

Perrin, R.M. 1977. Pest management in multiple cropping systems. Agro-Ecosystems 3: 93-118. 
Risch, S.J., Andow, D. \& Altieri, M.A. 1983. Agroecosystem diversity and pest control: data, tentative conclusions, and new research directions. Environmental Ent. 12: 625-629.

RonNI, P. 1987. Seosviljelyn vaikutus kauran kasvutapaan. Pro gradu -tyō, 77 p. Univ. Helsinki, Department of Crop Husbandry.

Stulpnagel, R. 1984. Proposal of a growth stages key for Vicia faba. In: Vicia faba: Agronomy, Physiology and Breeding, p. 9-14. (ed. P.D. Hebblethwaite, T.C.K. Dawkins, M.C. Heath \& G. Lockwood). The Hague.

Tottman, D.R. \& BRoad, H. 1987. The decimal code for the growth stages of cereals, with illustrations. Ann. Appl. Biol. 110: 441-454.

Trenbath, B.R. 1976. Plant interactions in mixed crop communities. ASA (American Society of Agronomy) Spec. Publ. 27: 129-169.

Vuluıoud, P. 1969. La culture du mélange féverole- avoine. Rev. Suisse d'Agric. 1: 42-43.

Weibull, J. 1987. Resistance in the genera Avena and Hordeum to the aphid Rhopalosiphum padi (L.) genetic resources and nutritional aspects. Diss., $32 \mathrm{p}$. Swedish Univ. Agric. Sci., Department of Plant and Forest Prot. Uppsala.

WILLEY, R.W. 1979. Intercropping - its importance and research needs. Field Crop Abstr. 32: 1-10, 73-85.

Williams, S. (ed.) 1984. Official methods of analysis of the Association of the Official Analytical Chemists. 14th ed. 1141 p. AOAC, Arlington, VA.

Wır, C.T. de 1960. On competition. Versl. Landbouwk. Onderzoek. 66.8. 82 p. Wageningen.

Wit, C.T. de \& Bergh, J.P. van den 1965. Competition between herbage plants. Neth. J. Agric. Sci. 13: $212-221$.

Ms received October 12, 1989

\section{SELOSTUS}

\section{Kasvien koko, ravinnepitoisuus ja kuiva- ainesato kauran ja härkäpavun seoskasvustoissa, sekä tuomikirva- saastunnan vaikutus näihin tekijöihin}

\author{
Juha Helenius \\ Helsingin yliopisto, Maatalous- ja \\ metsäeläintieteen laitos, \\ $00710 \mathrm{Helsinki}$
}

Kolmessa kenttăkokeessa vuosina 1983-1985 selvitettiin kauran (Nasta 1983, Puhti 1984-1985) ja härkäpavun (Mikko) sekaviljelyn vaikutusta näiden kasvien kasvutapaan, ravinnepitoisuuteen ja kuiva-ainesatoon. Koejäsenet olivat kauran ja pavun puhdaskasvustot ja korvaussarjoina järjestetyt sekakasvustot, joissa oli joko $2 / 3$ kauraa $+1 / 3$ papua tai $1 / 3$ kauraa $+2 / 3$ papua puhdaskasvustojen kylvömäăristă. Yhdessă kokeessa (1985) toisena faktoriaalisena koetekijänă oli tuomikirvan (Rhopalosiphum padi) torjunta deltametriiniruiskutuksin. Tăssä kokeessa mitattiin myös tuomikirvapopulaatioiden kasvun aikaiset päivittäiset lämpötilaminimit ja -maksimit kasvustojen sisältä.

Sekaviljely joko ei vaikuttanut kauran versojen kokoon tai lisäsi sitä. Papu jäi seoksissa yleensä lyhyemmäksi ja kevyemmäksi kuin puhdaskasvustoissa. Tuomikirvan torjuntaruiskutuksen ja kasvustotyypin välillă oli merkitsevă yhdysvaikutus, siten ettă puhtaassa kasvustossa torjunta lisăsi kauran paaăversojen pituutta ja massaa văhiten ja papuvaltaisessa seoksessa eniten; keskiarvojen pe- rusteella vaikutus papuun oli juuri päinvastainen, mutta ei tilastollisesti merkitsevă. Tulosten tulkittiin kuitenkin tukevan hypoteesia lajienvälisestă satokompensaatiosta sekakasvustossa, tilanteessa jossa tuholaisvioitus kohdistuu komponenttilajeista vain yhteen. Samansuuntainen tulos on aikaisemmin raportoitu saman kokeen siemensadoista (Helenius ja RonNi 1989).

Yhdessă kokeista kauran maanpäällisten osien typpi-, fosfori-, kalium-, ja magnesium-pitoisuudet (kuivaaineessa) olivat merkitsevăsti suurempia seoksissa kuin puhdaskasvustossa, suurimpia papuvaltaisessa seoksessa. Kaikkien näiden ravinteiden sekä kalsiumin pitoisuudet laskivat merkitsevästi kauran röyhylletulosta maitotuleentumisvaiheen alkuun, mutta kasvustotyyppien välinen ero ei riippunut kehitysasteesta. Samassa kokeessa pavun fosfori- ja kalium-pitoisuudet olivat merkitsevästi pienempiă seos- kuin puhdaskasvustoissa. Luontevin selitys tälle tulokselle on se, ettă vallinneissa kasvuoloissa kaura hyötyi pavun typensidonnasta ja oli papua voimakkaampi juuristokilpailussa fosforista ja kaliumista. 
Suhteellisten kokonaissatojen vertailu osoitti, ettă kuiva-aineen tuotannossa seokset eivăt olleet puhdaskasvustoja edullisempia. Kuiva-ainesadot mitattiin kauran maitotuleentumisvaiheen alussa, jolloin papu oli palkojen tăyttymisvaiheessa. Kokeessa, jossa kauran typpipitoisuus nousi sekaviljelyn ansiosta, typpisato muodostui $20 \%$ suuremmaksi kuin puhdaskasvustojen typpisatojen perusteella olisi voitu odottaa. Puhdas kaura tuotti siis suurimmat kuiva-ainesadot ja puhdas papu tai papuvaltainen seos suurimmat typpisadot.

Tuomikirvapopulaatioiden kasvun aikaan, kauran versoutumisen alkamisesta korren pidentymiseen, päivittăiset maksimilämpötilat noin $2 \mathrm{~cm}: n$ korkeudella maan pinnasta olivat papuvaltaisessa seoksessa keskimäärin $1.0^{\circ} \mathrm{C}$ :tta korkeammat kuin puhtaassa kaurakasvustossa. Vastaavaa eroa minimilămpötiloissa ei havaittu.

Tulokset osoittivat ettă sekaviljelyyn siirtyminen voi aiheuttaa kasvien koossa ja koostumuksessa sekä kasvuston mikroilmastossa muutoksia, jotka osaltaan selittăvăt sekaviljelyn vaikutusta tuhohyönteisten runsauteen ja vahingollisuuteen. Sekaviljelyn aiheuttamat muutokset tuholaisten runsaudessa ja vahingollisuudessa, sekä lajienvălisen satokompensaation mahdollisuus edellyttävăt torjunnan kynnysarvojen tarkistamista aina sekaviljelyyn siirryttäessä. 